Jrnal Ilmiah Ibnu Sina, 6(1), Maret 2021, 79-86

p-ISSN: 2502-647X; e-ISSN: 2503-1902

\title{
PENGGUNAAN INSULIN PADA PASIEN DIABETES MELITUS TIPE 2 PESERTA JKN DI INSTALASI FARMASI RAWAT JALAN RUMAH SAKIT ST. ELISABETH SEMARANG
}

\author{
Fef Rukminingsih*, Valentina Catur Nova \\ Politeknik Katolik Mangunwijaya Semarang \\ *Email: fefrukminingsih@gmail.com
}

Artikel diterima: 30 September2020; Disetujui: 22 Maret 2021

DOI: https://doi.org/10.36387/jiis.v6i1.609

\begin{abstract}
ABSTRAK
Diabetes Melitus (DM) tipe 2 merupakan suatu sindroma klinik yang berlangsung kronis dan progresif yang ditandai dengan poliuri, polidipsi dan polifagi disertai peningkatan glukosa darah atau hiperglikemia. Penatalaksanaan DM tipe 2 pada pasien dengan nilai $\mathrm{HbA1C}>9 \%$ adalah dengan pemberian insulin atau kombinasi insulin dengan obat hipoglikemik oral. Penelitian ini bertujuan untuk mengetahui kesesuaian jenis dan dosis insulin pada pasien DM tipe 2 di Instalasi Farmasi Rawat Jalan Rumah Sakit St. Elisabeth Semarang.

Penelitian ini merupakan penelitian deskriptif observasional dengan menggunakan data retrospektif. Pengambilan sampel menggunakan teknik purposive sampling. Data diperoleh dari rekam medik pasien peserta JKN dengan DM tipe 2 di Instalasi Farmasi Rawat Jalan Rumah Sakit St. Elisabeth Semarang yang hanya mendapat terapi insulin pada bulan Januari 2020, berumur 26-65 tahun, dan mempunyai hasil pemeriksaan GDP, GDPP dan HbA1C (hasil pemeriksaan 6 bulan terakhir).

Hasil penelitian menunjukkan sebanyak 57 pasien terdiri dari $29(50,88 \%)$ pasien laki-laki dan $28(49,12 \%)$ pasien perempuan. Sebanyak $47(82,46 \%)$ pasien berumur lebih dari 45 tahun. Sebanyak 38 pasien $(66,67 \%)$ mendapat insulin kombinasi dan semua pasien mempunyai nilai $\mathrm{HbA} 1 \mathrm{C}>9 \%$. Kesuaian penggunaan insulin berdasarkan jenis insulin sebesar 68,42\% dan sebagian besar pasien $(80,70 \%)$ mendapat dosis insulin yang tidak sesuai.
\end{abstract}

Kata kunci: insulin, DM tipe 2, RS St. Elisabeth Semarang

\section{ABSTRACT}

Diabetes mellitus (DM) type 2 is a chronic and progressive clinical syndrome, characterized by polyuria, polydipsi and polyphagy accompanied by increased blood glucose or hyperglycemia. Management of type 2 diabetes mellitus in patients with HbAlC values $>9 \%$ is by administering insulin or a combination of insulin with oral hypoglycemic agents. This study aims to determine the suitability of the type and dose of insulin in type 2 DM patients in the Outpatient Pharmacy Installation of St. Elisabeth Hospital Semarang.

This research is a descriptive observational study using retrospective data. Sampling using purposive sampling technique. The data were obtained from the 
Jrnal Ilmiah Ibnu Sina, 6(1), Maret 2021, 79-86

p-ISSN: 2502-647X; e-ISSN: 2503-1902

medical records of Universal Health Coverage participant patients with type 2 diabetes mellitus in the Outpatient Pharmacy Installation of St. Elisabeth Hospital Semarang, who only received insulin therapy in January 2020, is 26-65 years old, and has examination results for fasting blood glucose, post prandial blood glucose and $\mathrm{HbAlC}$ (examination results for the last 6 months).

The results showed that 57 patients consisted of 29 (50.88\%) male patients and $28(49.12 \%)$ female patients. A total of $47(82.46 \%)$ patients were more than 45 years old. A total of 38 patients (66.67\%) received combination insulin and all patients had HbAlC values> $9 \%$. The suitability of using insulin based on the type of insulin was $68.42 \%$ and most of the patients (80.70\%) received inappropriate insulin doses.

Keywords: insulin, DM type 2, St. Elisabeth Hospital Semarang

\section{PENDAHULUAN}

Diabetes Melitus (DM) merupakan penyakit kronik yang terjadi karena pankreas tidak dapat menghasilkan insulin secara cukup atau karena resistensi insulin (WHO, 2016). DM adalah suatu sindroma klinik yang berlangsung kronis dan progresif ditandai oleh poliuri, polidipsi dan polifagi disertai peningkatan glukosa darah atau hiperglikemia (Perkeni, 2015). Data Sample Registration Survey tahun 2014 menunjukkan bahwa DM penyebab kematian terbesar nomor 3 di Indonesia. Persentase angka kematian yang disebabkan oleh penyakit DM sebesar $6,7 \%$, setelah stroke $(21,1 \%)$ dan penyakit jantung koroner (12,9\%) (Kemenkes RI, 2014). Berdasarkan hasil Riset Kesehatan Dasar tahun 2018, diketahui peningkatan jumlah pasien DM tipe 2 di Indonesia sebesar 4\% dari tahun 2013 sebanyak 6,9\% hingga tahun 2018 sebanyak 10,9\% (Kemenkes RI, 2018a).

DM yang tidak terkontrol akan menimbulkan komplikasi akut dan kronis. Komplikasi akut berupa hipoglikemia maupun hiperglikemia. Komplikasi kronik berupa komplikasi makrovaskuler dan mikrovaskuler (Fatimah, 2015).

Penatalaksanaan DM tipe 2 yang mempunyai hasil pemeriksaan HbA1C lebih dari 9\% adalah dengan pemberian insulin (Perkeni, 2015). Insulin rapid acting diberikan bila kadar gula darah 2 jam setelah makan $($ GDPP $) \geq 200 \mathrm{mg} / \mathrm{dL}$, insulin long acting diberikan bila gula darah puasa $($ GDP $) \geq 126 \mathrm{mg} / \mathrm{dL}$ dan insulin kombinasi (mix insulin) diberikan bila 
Jrnal Ilmiah Ibnu Sina, 6(1), Maret 2021, 79-86

p-ISSN: 2502-647X; e-ISSN: 2503-1902

GDP $\geq 126 \mathrm{mg} / \mathrm{dL}$ dan GDPP $\geq 200$ $\mathrm{mg} / \mathrm{dL}$ (Kemenkes RI, 2018b).

Kesalahan pengobatan yang berhubungan dengan insulin adalah kesalahan pemberian jenis dan dosis insulin. Lebih dari 52\% dari kejadian yang dilaporkan, adanya kemungkinan pasien memiliki atau menerima dosis dan jenis insulin yang salah sehingga dapat menyebabkan hiperglikemia (Pennsylvania Patient Safety Authority, 2010).

Rumah Sakit St. Elisabeth Semarang merupakan Rumah Sakit tipe B yang menjadi rumah sakit rujukan dalam menangani kasus DM tipe 2. DM termasuk dalam sepuluh besar penyakit yang ada di Rumah Sakit St. Elisabeth Semarang. Berdasarkan latar belakang tersebutmaka perlu dilakukan penelitian untuk mengevaluasi kesesuaian penggunaan insulin pada pasien DM tipe 2 di Instalasi Farmasi Rawat Jalan Rumah Sakit St. Elisabeth Semarang.

\section{METODE PENELITIAN}

Penelitian ini merupakan penelitian deskriptif observasional dengan menggunakan data retrospektif. Pengambilan sampel menggunakan teknik purposive sampling. Data diperoleh dari rekam medik pasien peserta JKN dengan DM tipe 2 di Instalasi Farmasi Rawat Jalan Rumah Sakit St. Elisabeth Semarang yang hanya mendapat terapi insulin pada bulan Januari 2020, berumur 2665 tahun, dan mempunyai hasil pemeriksaan GDP, GDPP dan HbA1C (hasil pemeriksaan dalam 6 bulan terakhir). Analisis data dilakukan secara kualitatif menurut karakteristik pasien dan secara kuantitatif dengan menghitung persentase kesesuaian penggunaan jenis dan dosis insulin.

\section{HASIL DAN PEMBAHASAN}

Berdasarkan hasil penelusuran data rekam medik diketahui pasien DM tipe 2 yang mempunyai hasil pemeriksaan GDP, GDPP, HbA1C dan hanya mendapat terapi insulin sebanyak 57 pasien. Karakteristik pasien DM tipe 2 yang mendapat mendapat terapi insulin di RS St. Elisabeth Semarang dapat dilihat pada Tabel 1.

Berdasarkan Tabel 1 diketahui bahwa jumlah pasien DM tipe 2 berjenis kelamin laki-laki lebih 
Jrnal Ilmiah Ibnu Sina, 6(1), Maret 2021, 79-86

p-ISSN: 2502-647X; e-ISSN: 2503-1902

banyak. Laki-laki mempunyai risiko lebih besar mengalami DM dibanding perempuan (Alghadir dkk, 2014). Penelitian dengan hasil yang hampir sama dilakukan di Yogyakarta pada tahun, yaitu laki-laki $(54,55 \%)$ lebih banyak dibandingkan perempuan (45,45\%) (Andayani dkk, 2010).

Penelitian dengan hasil yang berbeda, dimana pasien perempuan lebih dibandingkan pasien laki-laki dilakukan di Surabaya (Pranoto dkk, 2015), di Pekanbaru (Inayah dkk, 2016) dan di Bali ( Gamayanti dkk, 2018). Sebagian besar pasien $(82,46 \%)$ berumur $\geq 45$ tahun. Kejadian DM tipe 2 meningkat dengan bertambahnya umur karena umur merupakan salah satu faktor risiko terjadinya DM (Kurniawaty, 2016). Peningkatan umur menyebabkan perubahan metabolisme karbohidrat, perubahan pelepasan insulin yang dipengaruhi oleh glukosa dalam darah dan terhambatnya pelepasan glukosa yang masuk ke dalam sel karena dipengaruhi oleh insulin (Brunner dan Suddarth, 2013). Selain itu umur juga mempengaruhi penurunan pada semua sistem tubuh, tidak terkecuali sistem endokrin. Peningkatan umur dapat menyebabkan kondisi resistensi insulin yang berakibat meningkatnya level gula darah (Isnaini dan Ratnasari, 2018).

Tabel 1. Karakteristik pasien DM

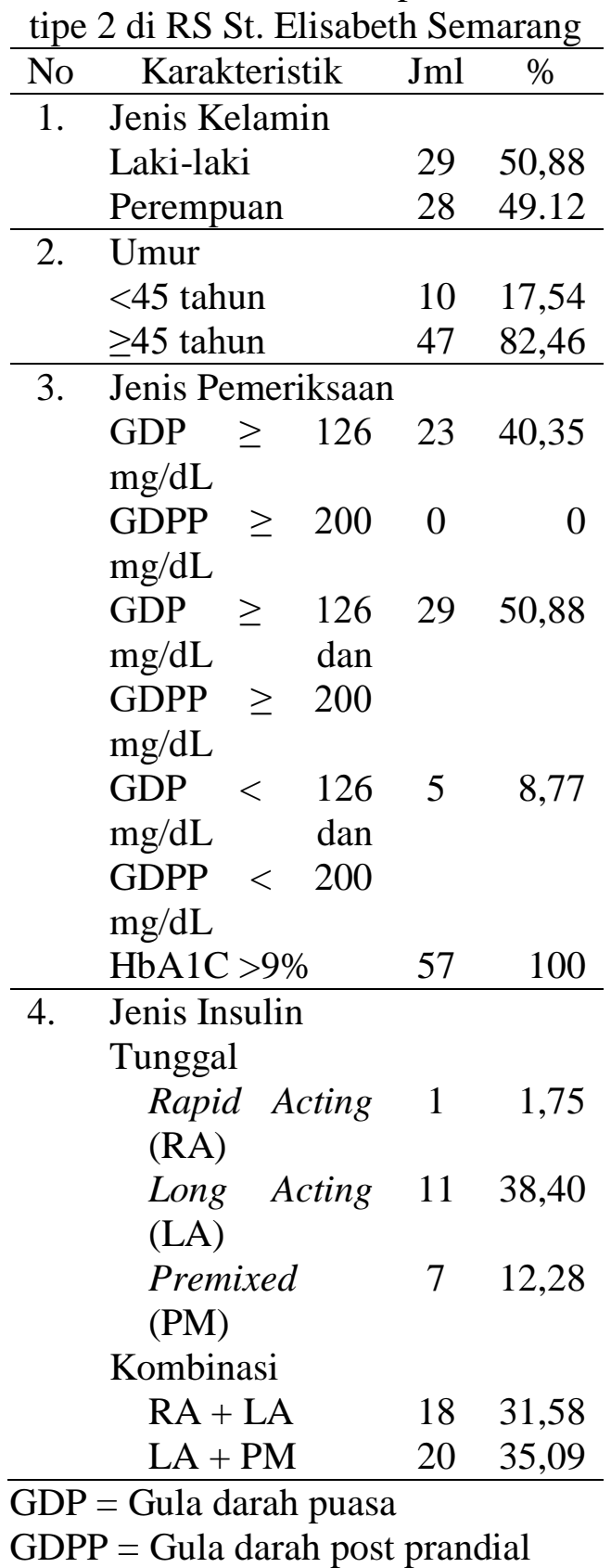


Jrnal Ilmiah Ibnu Sina, 6(1), Maret 2021, 79-86

p-ISSN: 2502-647X; e-ISSN: 2503-1902

Sebanyak 29 pasien $(50,88 \%)$ mempunyai hasil pemeriksaan GDP $\geq 126 \mathrm{mg} / \mathrm{dL}$ dan GDPP $\geq 200 \mathrm{mg} / \mathrm{dL}$. Kadar GDP dan GDPP dapat fluktuatif selama 24 jam dari hari ke hari pada pasien DM sehingga kadar gula darah tersebut tidak bisa menggambarkan keadaan gula darah yang sesungguhnya dan sulit untuk mengetahui pengontrolan kadar gula darah secara objektif karena kedua pemeriksaan tersebut sangat dipengaruhi dengan gaya hidup jangka pendek pasien (makanan, minuman dan aktivitas fisik) sebelum melakukan pemeriksaan. Pemeriksaan yang dapat digunakan untuk memonitor pengontrolan kadar gula darah secara objektif adalah pemeriksaan HbA1C. HbA1C adalah protein yang terbentuk dari perpaduan antara glukosa dan hemoglobin dalam sel darah merah. Nilai HbA1C tidak dipengaruhi oleh fluktuasi konsentrasi gula darah harian dan juga gaya hidup jangka pendek pasien. Pemeriksaan $\mathrm{HbA1C}$ dapat mencerminkan pengendalian metabolisme gula darah selama tiga bulan sebelumnya (Charisma, 2017). Semua pasien dalam penelitian ini mempunyai nilai $\mathrm{HbA} 1 \mathrm{C}>9 \%$.

Sebanyak 38 pasien $(66,67 \%)$ mendapat terapi kombinasi insulin baik kombinasi rapid acting dengan long acting maupun intermediate acting. Kombinasi insulin dapat memberikan penurunan kadar glukosa darah lebih baik karena dapat memenuhi kebutuhan insulin basal dan insulin prandial, mengontrol fluktuasi glukosa darah, kejadian hipoglikemia dan peningkatan berat badan lebih terkontrol (Baso dkk, 2014).

Tabel 2. Penggunaan insulin di RS

\begin{tabular}{clcc}
\multicolumn{4}{l}{ St. Elisabeth Semarang } \\
\hline No. & Kesesuaian & Jumlah & $\%$ \\
\hline 1. & Jenis Insulin & & \\
& Sesuai & 39 & 68,42 \\
& Tidak sesuai & 18 & 31,58 \\
\hline 2. & Dosis & & \\
& Insulin & & \\
& Sesuai & 11 & 19,30 \\
& Tidak sesuai & 46 & 80,70 \\
\hline
\end{tabular}

Berdasarkan Tabel 2 diketahui kesesuaian pemilihan jenis insulin pada pasien DM tipe 2 sebesar $68,42 \%$. Pemilihan jenis insulin dinyatakan sesuai bila memenuhi ketentuan/retriksi dari formularium nasional, yaitu bila GDPP $\geq 200$ $\mathrm{mg} / \mathrm{dL}$ diberikan insulin rapid acting. 
Jrnal Ilmiah Ibnu Sina, 6(1), Maret 2021, 79-86

p-ISSN: 2502-647X; e-ISSN: 2503-1902

Bila GDP $\geq 126 \mathrm{mg} / \mathrm{dL}$ diberikan

mendapatkan dosis yang lebih kecil, insulin long acting. Sedangkan bila GDP $\geq 126 \mathrm{mg} / \mathrm{dL}$ dan GDPP $\geq 200$ $\mathrm{mg} / \mathrm{dL}$ maka diberikan insulin kombinasi (mix insulin) (Kemenkes RI, 2018b). Sebanyak 18 pasien mendapat jenis insulin yang tidak tepat, terdiri dari 15 pasien yang mempunyai hasil pemeriksaan GDP $\geq$ $126 \mathrm{mg} / \mathrm{dL}$ tetapi GDPP $\leq 200 \mathrm{mg} / \mathrm{dL}$ mendapatkan terapi insulin kombinasi dan 2 pasien yang mempunyai hasil pemeriksaan GDP $\geq 126 \mathrm{mg} / \mathrm{dL}$ dan GDPP $\geq 200 \mathrm{mg} / \mathrm{dL}$ mendapatkan terapi insulin long acting. Sedangkan 1 pasien mempunyai GDPP 152 $\mathrm{mg} / \mathrm{dL}$ tetapi mendapat insulin rapid acting.

Dalam penelitian ini, kesesuaian dosis insulin dihitung berdasarkan kebutuhan insulin harian total (IHT) yaitu 0,2-0,5 unit untuk setiap kilogram berat badan. Kebutuhan insulin prandial total (IPT) adalah 60\% dari IHT. Sedangkan kebutuhan insulin basal total (IBT) sebesar $40 \%$ daru IHT (Cheng and Zinman, 2005). Sebanyak 11 pasien DM tipe $2(11,30 \%)$ yang mendapat dosis insulin yang sesuai berdasarkan berat badan pasien. Sebanyak 2 pasien

sedangkan sebanyak 44 pasien mendapat dosis insulin yang lebih besar berdasarkan perhitungan berat badannya. Pemberian dosis yang lebih besar dilakukan karena dokter melakukan penyesuaian dosis untuk mencapai target terapi. Beberapa faktor yang mempengaruhi penggunaan insulin pada pasien diantaranya, tingkat pendidikan, tingkat pengetahuan terhadap penyakit, kepatuhan berobat, dan pengaturan dosis insulin yang belum maksimal. Salah satu penyebab utama pengaturan dosis yang tidak optimal dikarenakan adanya penyakit penyerta. Semakin tinggi tingkat pengetahuan pasien terhadap penyakitnya dan cara menggunakan insulin, maka semakin tepat dosis insulin yang dapat diberikan (Gamayanti dkk, 2018). Perlu dilakukan peningkatan edukasi pada pasien supaya lebih patuh pada regimen terapi yang diperoleh. Keterbatasan dalam penelitian ini adalah tidak mencantumkan jumlah dan jenis penyakit penyerta. Semua pasien mempunyai nilai $\mathrm{HbA} 1 \mathrm{C}>9 \%$ sehingga perlu dilakukan terapi 
Jrnal Ilmiah Ibnu Sina, 6(1), Maret 2021, 79-86

p-ISSN: 2502-647X; e-ISSN: 2503-1902

intensifikasi insulin supaya $\mathrm{HbA1C}$ mencapai target terapi (American Diabetes Association, 2018).

\section{KESIMPULAN}

Kesesuaian penggunaan insulin pada pasien DM tipe 2 peserta JKN di RS St. Elisabeth Semarang berdasarkan jenis insulin sebesar $68,42 \%$ dan sebagian besar pasien $(80,70 \%)$ mendapat dosis insulin yang tidak sesuai.

\section{UCAPAN TERIMA KASIH}

1. Direktur RS St. Elisabeth Semarang.

2. Direktur Politeknik Katolik Mangunwijaya Semarang.

\section{DAFTAR PUSTAKA}

Alghadir A, Awad H, Al-Eisa E, Alghwiri A, 2014, Diabetes risk 10 years forecast in the capital of Saudi Arabia: Canadian diabetes risk assessment questionnaire (CANRISK) perspective. Biomed Res, 25(1), 88-96.

American Diabetes Association, 2018, Pharmacologic approaches to glycemic treatment: Standards of Medical Care in Diabetes, Diabetes Care, 41(Suppl. 1), S73-S85.

Andayani TM, Ibrahim MIM, Asdie $\mathrm{AH}, 2010$, Comparison of the glycemic control of insulin and triple oral therapy in type 2 diabetes mellitus. $J$ Diabetes Endocrinol, 1(2), 13-8

Baso AY, Umar H, dan Manggau MA, 2014, Pengaruh Terapi Terhadap Pasien Diabetes Melitus Tipe 2 Preoperatif, Skripsi, Universitas Hasanudin, Makasar.

Brunner dan Suddarth, 2013, Buku Ajar Keperawatan Medikal Bedah. Edisi 8 Volume I, EGC, Jakarta.

Charisma AM, 2017, Korelasi Kadar Rata-Rata Glukosa Darah Puasa dan 2 Jam Post Prandial Tiga Bulan Terakhir dengan Nilai HbA1C pada Pasien Diabetes Melitus Prolanis BPJS Kabupaten Kediri Periode MeiAgustus 2017, https://jurnal.unimus.ac.id, 15 Juli 2020.

Cheng AYY, Zinman B, Khan CR, 2005, Joslin's Diabetes Mellitus, Fourth Edition, Lipincott Williams \& Wilkins, Philadelphia.

Fatimah RN, 2015, Diabetes Melitus tipe 2, Majority Jurnal, 4 (5), 93101.

Gamayanti V, Ratnasari NLMN, Bhargah A, 2018, Pola penggunaan insulin pada pasien diabetes mellitus tipe 2 di poli penyakit dalam RSU Negara Periode Juli - Agustus 2018, Intisari Sains Medis, 9(3), 6873.

Inayah, Hamidy MY, Yuki RPR, 2016, Pola penggunaan insulin pada pasien diabetes melitus tipe 2 rawat inap di Rumah Sakit X Pekanbaru tahun 2014, JIK, 10(1), 38-43 
Jrnal Ilmiah Ibnu Sina, 6(1), Maret 2021, 79-86

p-ISSN: 2502-647X; e-ISSN: 2503-1902

Isnaini Nur, dan Ratnasari, 2018, Faktor Risiko Mempengaruhi Kejadian Diabetes Melitus tipe II,

https://ejournal.unisyogya.ac.id, 15 Juli 2020

Kementerian Kesehatan Republik Indonesia, 2014, Situasi dan AnalisisDiabetes, Kementerian Kesehatan Republik Indonesia, Jakarta.

Kementerian Kesehatan Republik Indonesia, 2018a, Hasil Utama Riset Kesehatan Dasar, Badan Penelitian dan Pengembangan Kesehatan, Jakarta.

Kementerian Kesehatan Republik Indonesia, 2018b, Perubahan atas Keputusan Menteri Kesehatan Nomor HK.01.07/Menkes/659/2017 tentang Formularium Nasional, Kementerian Kesehatan Republik Indonesia, Jakarta.

Kurniawaty, Evi dan Bella Yanita, 2016, Faktor-Faktor yang Berhubungandengan Kejadian Diabetes Melitus tipe II, https://juke.kedokteran.unila.ac. id, Tanggal 12 Juli 2020.

Perkeni, 2015, Konsensus: Pengelolaan dan Pencegahan Diabetes Melitus tipe 2 di Indonesia, PB Perkeni, Jakarta.

Pennsylvania Patient Safety, 2010, Medication Errors with the Dosing of Insulin: Problems across the Continuum Advisory Patient Safety Authority, 7(1), 917.

Pranoto A, Novida H, Prajitno JH, Tjokroprawiro A, 2015, Safety and efficacy in early insulin initiation as comprehensive therapy for patients with type 2 diabetes in primary health care centers. Acta Med Indonesia, 47(2), 104-10

World Health Organization (WHO), 2016, Global Report on Diabetes, World Health Organization, Geneva. 